\title{
SISTEM PENDUKUNG KEPUTUSAN PEMILIHAN PRAMUKA PANDEGA BERPRESTASI MENGGUNAKAN METODE MULTI OBJECTIVE OPTIMIZATION ON THE BASIS OF RATIO ANALYSIS
}

\author{
Ramadiani $^{1}$, Famylia Puspa Rani ${ }^{2}$, Dyna Marisa Khairina ${ }^{3}$, Heliza Rahmania Hatta ${ }^{4}$ \\ 1,2,3 Jurusan lmu Komputer, Fakultas Ilmu Komputer dan Teknologi Informasi \\ Universitas Mulawarman Samarinda, Indonesia \\ Email: 1ilkom.ramadiani@gmail.com, ${ }^{2}$ famyliapusparani23@gmail.com, ${ }^{3}$ dyna.ilkom@gmail.com, \\ heliza_rahmania@yahoo.com,
}

(Naskah masuk: 25 November 2018, diterima untuk diterbitkan: 18 Desember 2018)

\begin{abstract}
Abstrak
Pemilihan Pramuka Pandega berprestasi adalah agenda tahunan yang diselenggarakan oleh Pengurus Daerah Gerakan Pramuka Provinsi Kalimantan Timur. Kegiatan ini bertujuan untuk memilih wakil Pandega yang akan dikirim ke Jakarta. Pemilihan Pramuka Pandega yang terbaik didasarkan pada kriteria usia, Indeks Prestasi Kumulatif, jumlah perkemahan wirakarya yang pernah diikuti, kepribadian dan penampilan, peluang kerja yang dimiliki dan pretasi lain serta karya tulis. Namun dengan cara penghitungan yang belum otomatisasi, hal ini dinilai cukup sulit, belum profesional, tidak objektif dan lambat bagi tim penilai. SPK disediakan untuk membantu tim penilai menyelesaikan pekerjaannya secara profesional dalam memutuskan siapa yang layak dipilih sebagai Pandega berprestasi secara mudah, objektif, professional dan transparan. Pemilihan Pandega berprestasi menggunakan metode MOORA, studi literatur dan wawancara pada tim penilai, serta metode waterfall untuk tahapan pengembangan sistemnya. Berdasarkan hasil dari beberapa penelitian, direkomendasikan metode MOORA sebab metode ini memungkinkan adanya penilaian cost dan benefit dalam keputusan akhirnya. Laporan akhir penelitian ini menghasilkan keputusan Pandega berprestasi berdasarkan nilai akurasi 100\%.
\end{abstract}

Kata kunci: Sistem Pendukung Keputusan, MOORA, Pramuka Pandega.

\section{DECISION SUPPORT SYSTEM TO SELECT PANDEGA SCOUT ACHIEVEMENT USING MULTI OBJECTIVE OPTIMIZATION ON THE BASIS OF RATIO ANALYSIS METHOD}

\begin{abstract}
Selection of Scouts Pandega achievers are an annual agenda organized by the Regional Board of the Scout Movement of East Kalimantan Province. This activity aims to elect Pandega representatives to be sent to Jakarta. The best selection of Pandega Scouts is based on the criteria of age, Grade Point Average, number of workshops that have been attended, personality and appearance, work opportunities that are owned and other achievements and writing. However, with calculations that have not been automated, this is considered quite difficult, not professional, not objective and slow for the assessment team. DSS is provided to help the assessment team complete their work professionally in deciding who is eligible to be chosen as Pandega to achieve easily, objectively, professionally and transparently. The selection of Pandega achieves using the MOORA method, literature study and interviews with the assessment team, and the waterfall method for the development stages of the system. Based on the results of several studies, the MOORA method is recommended because this method allows an assessment of the costs and benefits in the final decision. The final report of this study resulted in Pandega's achievement achievement based on $100 \%$ accuracy value.
\end{abstract}

Keywords: Decision Support System, MOORA, Pandega Scout.

\section{PENDAhULUAN}

Kepramukaan merupakan salah satu kegiatan extra kurikuler pada gugus depan di satuan pendidikan dan satuan karya pramuka pada lingkup pendidikan dan kebudayaan. Pada Permendikbud 62 Tahun 2014 dan Permendikbud 63 Tahun 2014, yang mengatur implementasi pendidikan kepramukaan sebagai ekstrakulikuler wajib, telah dilaksanakan dengan maksimal. Sejak tahun 2015 kwartir daerah menjadi 10 kwartir cabang dengan data potensi peserta didik di kwartir cabang gerakan Pramuka Kalimantan Timur periode 2011-2016 
yaitu: Siaga 59,622 anggota, Penggalang 80,259 anggota, Penegak 34,040 anggota, Pandega 5,207 anggota dengan total keseluruhan 179,128 anggota Gerakan Pramuka.

Sebagai pramuka semestinya berusaha memiliki prestasi atas apa yang telah diusahakan maupun kegiatan yang telah dilakukan, pramuka berprestasi berarti ia mampu berkarya nyata sesuai dengan kemampuan. Oleh karena itu untuk mengukur tingkat kemampuan atau prestasi tersebut diadakannya pemilihan pramuka berprestasi. Pemilihan Pramuka Pandega Berprestasi setiap tahunnya peserta bisa mencapai lebih dari 5 orang dan pemenangnya akan mendapatkan gelar terbaik 1, 2 dan 3.

Berdasarkan penelitian-penelitian sebelumnya metode MOORA dipilih karena memiliki keunggulan dengan perhitungan yang sederhana, serta memilki nilai cost dan benefit dalam menghasilkan rekomendasi yang tepat. Metodologi ini mempunyai tingkat selektifitas yang baik karena dapat menentukan tujuan dari kriteria yang bertentangan. Dimana kriteria dapat bernilai menguntungkan (benefit) atau yang tidak menguntungkan (cost). Beberapa penelitian lainnya menunjukan bahwa tingkat akurasi yang dihasilkan dari metode MOORA mencapai $100 \%$. Topik yang digunakan dalam penelitian ini belum pernah dibahas dalam penelitian sebelumnya sehingga cukup menarik untuk diimplementasikan mengguna MOORA.

Pemilihan pramuka berprestasi selama ini masih dianggap professional, kurang efisien, subjektif dan tertutup. Begitu juga penilaian pembobotan setiap kriteria masih dinilai merata, belum terdapat pembobotan yang proporsional, sehingga dianggap dapat merugikan peserta dan dianggap masih rawan dengan kecurangan. Sesuai dengan permasalahan tersebut di atas, adapun tujuan penelitian ini mengembangkan SPK yang bisa memberikan merekomendasi keputusan secara mudah, cepat, tepat, transparan dan objektif berdasarkan kriteria yang sudah disepakati seperti usia, Indeks Prestasi Kumulatif, jumlah Perkemahan Wirakarya yang pernah diikuti, Kepribadian dan Penampilan, Peluang Kerja dan Prestasi lain serta Karya Tulis.

\section{METODE MOORA}

Multi-Objective Optimization by Ratio Analysis (MOORA) adalah salah satu cara penghitungan matematik untuk SPK dipopulerkan oleh Brauers berserta Zavadkas. Menurut Mandal dan Sarkar pada tahun 2012 metode yang diperkenalkan Brauers ini relatif baru digunakan untuk pengambilan keputusan dengan multikriteria. Metode ini menempati level fleksibilitas serta kemudahan untuk diikuti pada saat pembagian kriteria subjektif saat tahapan evaluasi ke dalam kriteria bobot keputusan, yang multivariabel.
Metode ini telah diterapkan dibeberapa bidang sosial manajemen, ekonomi dan pembangunan, juga bidang sain seperti desain jalan dan kontraktor. Tingkat selektifitas MOORA cukup baik ketika menetapkan suatu alternatif, karena memaksimalkankan pemilihan alternatif sesuai perbedaaan kriteria pada setiap masalah secara bersamaan.

Setidaknya metode ini memilki lima tahapan yang harus diikuti:

Tahap 1: memiliki tujuan yang jelas dan atribut evaluasi yang akan diidentifikasi.

Tahap 2: memunculkan semua kriteria yang ada dalam penelitian berbentuk matriks keputusan. $X$ merupakan nilai atribut pada setiap atribut, yang diperesentasikan dalam bentuk perkalian sebagai berikut:

$X=\left[\begin{array}{cccc}x_{11} & x_{12} & \cdot & x_{1 n} \\ x_{21} & x_{22} & \cdot & x_{2 n} \\ \cdot & \cdot & \cdot & \cdot \\ x_{m 1} & x_{m 2} & \cdot & x_{m n}\end{array}\right]$

Tahap 3: membuat kesimpulan tentang denominator, yang merupakan pilihan terbaik dari penjumlahan kuadrat dari akar kuadran pada setiap atribut. Rumusnya adalah:

$$
X^{*}{ }_{i j}=\frac{x_{i j}}{\sqrt{\sum_{j=1}^{m} x_{i j}^{2}}}
$$

Rasio $X_{\mathrm{ij}=}$ alternatif ke 1 pada kriteria ke $\mathrm{j}, \mathrm{m}=$ jumlah alternative, $\mathrm{n}=$ jumlah kriteria.

Tahap 4: Pada multi-objective optimization, hasil normalisasi adalah pemaksimalan penjumlahan atribut yang menguntungkan (benefit) dan peminimalan pengurangan atribut yang tidak menguntungkan (cost). Sehingga penghitungan optimalisasi menjadi:

$$
Y_{i}=\sum_{j=1}^{g} x_{i j} \sum_{j=g+1}^{n} x_{i j}
$$

Dimana $\mathrm{g}=$ nilai atribut yang dimaksimalkan, $(\mathrm{n}-\mathrm{g})=$ nilai atribut yang diminimalkan, $Y_{i}=$ nilai normalisasi alternatif $\mathrm{i}$ semua atribut. Pada kasus lain, kadang mengidentifikasi atribut yang dianggap penting. Atributatribut penting itu diberi bobot yang sesuai (signifikan koefisien). Jika bobot atribut penting ini dipertimbangkan, maka rumus $Y_{\mathrm{i}}$ sebagai berikut.

$$
Y_{i}=\sum_{j=1}^{g} w_{j} x_{i j} \sum_{j=g+1}^{n} w_{j} x_{i j}
$$

$\mathrm{W}_{\mathrm{j}}=$ bobot atribut $\mathrm{j}$.

Tahap 5: $Y_{i}$ bisa bernilai positif atau negatif, bergantung pada jumlah maksimal kriteria benefit dan minimal kriteria cost pada perkalian keputusan (matriks).

\subsection{Pandega}

Pandega adalah anggota Pramuka berusia sekitar 2125 tahun, atau disebut juga Senior Rover. Usia Pandega kadang disebut usia remaja madya, karena menuju kesadaran diri meraih cita-cita dan kematangan jiwa. Di usia Pandega, mulai berkurang sifat agresif, semakin 
meningkat jiwa sosial dan rasionalnya. Cakap, tegas, mandiri, idealis namun santun dalam kesehariannya. Kreatif berkarya dan kesadaran yang tinggi terhadap aturan

\section{TAHAPAN PENELITIAN}

Tahapan dalam penelitian ini melakukan proses wawancara kepada Ketua Bina Muda Kwartir Cabang Kalimantan Timur, untuk mengidentifikasi dan mengevaluasi permasalahan yang terjadi. Analisis yang dibutuhkan untuk menentukan input dan output pada sebuah sistem agar memudahkan dalam perhitungan. Berikut merupakan data kriteria pemilihan pramuka pandega berprestasi yaitu:

\subsection{Usia (C1)}

Gerakan Pramuka mengelompokkan setiap anggotanya berdasarkan usia. Mereka yang berusia 2125 tahun. Semakin dewasa umurnya maka semakin banyak pula pengalaman yang telah dimiliki oleh pandega tersebut sehingga nilai dalam kriterianya semakin tinggi.

\subsection{Indeks Prestasi Kumulatif (C2)}

IPK merupakan ukuran kemampuan mahasiswa sampai pada periode tertentu yang dihitung berdasarkan jumlah SKS pada setiap mata kuliah yang telah ditempuh. Sesuai dengan persyaratan pramuka pandega berprestasi nilai minimal 3.00 atau yang setara (rata-rata raport minimal 8 untuk tingkat SMA/SMK/MA).

\subsection{Perkemahan Wirakarya (C3)}

Merupakan perkemahan anggota pramuka yang dilaksanakan bagi pramuka penegak dan pandega yang terdiri dari berbagai satuan, untuk berintegrasi dengan masyarakat sekitar, berpartisipasi dan ikut berperan aktif mengisi pembangunan, seperti yang tertulis pada tri satya dan dhasa dharma penegak dan pandega, sekurangkurangnya perna mengikuti perkemahan wirakarya di tingkat cabang.

\subsection{Kepribadian dan Penampilan (C4)}

Merupakan penilaian bagaimana peserta menjadi contoh pribadi yang baik dimanapun dia berada. Kepribadian dan penampilan gerakan pramuka diatur dan tertulis pada Satya Dharma pramuka. Pandega tersebut diharapkan memiliki penampilan yang baik seperti kerapia dalam berpakaian, hormat, berbicara yang sopan dan sebagainya.

\subsection{Peluang Kerja dan Prestasi Lain (C5)}

Peluang kerja merupakan penilaian apabila peserta tersebut telah memiliki usaha untuk membiayai dirinya sendiri maupun bisa membuka peluang kerja bagi orang lain/anggota pramuka di gugus depannya sedangkan prestasi lain ialah prestasi yang diperoleh baik secara kademik ataupun non akademik contohnya mendapat penghargaan di bidang akademik tingkat nasional/ internasional seperti olimpiade fisika, penelitian ilmiah.
Sedangkan untuk prestasi non akademik seperti di bidang olahraga, seni, dan bakti masyarakat.

\subsection{Karya Tulis (C6)}

Merupakan persyaratan membuat karya tulis tentang kegiatan yang berdampak bagi masyarakat.

Nilai Bobot kriteria pada penelitian ini diperoleh melalui hasil persetujuan dari Ketua Bina Muda Kwartir Ranting Daerah Kalimantan Timur sehingga nilai bobot yang teah ditentukan tidak dapat diubah.

Adapun tabel keterangan dan konversi nilai sesuai dengan krteria yang telah ditentukan ialah sebagai berikut :

\begin{tabular}{cc} 
Tabel 3.1 Nilai Bobot (W) Kriteria \\
\hline Bobot & Nilai \\
\hline W1 & 0,12 \\
W2 & 0,21 \\
W3 & 0,25 \\
W4 & 0,10 \\
W5 & 0,18 \\
W6 & 0,14 \\
\hline
\end{tabular}

\section{HASIL PENELITIAN}

\subsection{Deskripsi Program}

Aplikasi SPK penetapan pramuka pandega berprestasi dalam penelitian ini memakai penghitungan MOORA menggunakan desktop, tujuannya agar mengurangi kesulitan tim penilai untuk menetapkan urutan pandega terpilih sesuai dengan nilai yang direkomndasikan sebagai pandega berprestasi. Pada sistem ini terdapat beberapa halaman yaitu halaman beranda, halaman kepesertaan, halaman penilaian, login administrator dan halaman laporan. Untuk halaman beranda ditampilkan di Gambar 1 .

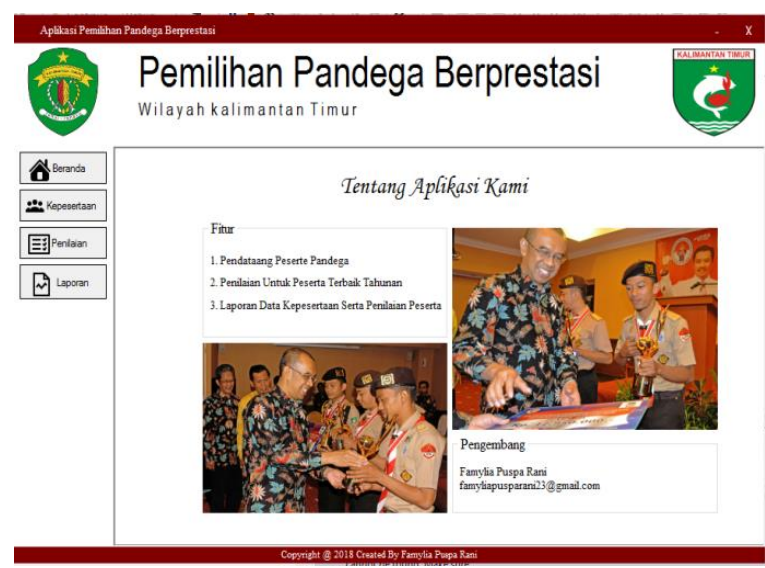

Gambar 1. Beranda

Setelah admin login maka segera terbuka halaman beranda pada tampilan Gambar 2, dimana terdapat menu kepesertaan, penilaian dan laporan. Untuk melanjutkan perhitungan MOORA maka tahap pertama yang dilakukan yatu memasukan data calon peserta pramuka pandega berprestasi kedalam menu kepesertaan seperti Gambar 2 dimana admin dapat mengubah, menghapus dan menyimpan data, tahap kedua memasukan nilai alternatif sesuai dengan kriteria yang dapat dilihat pada 


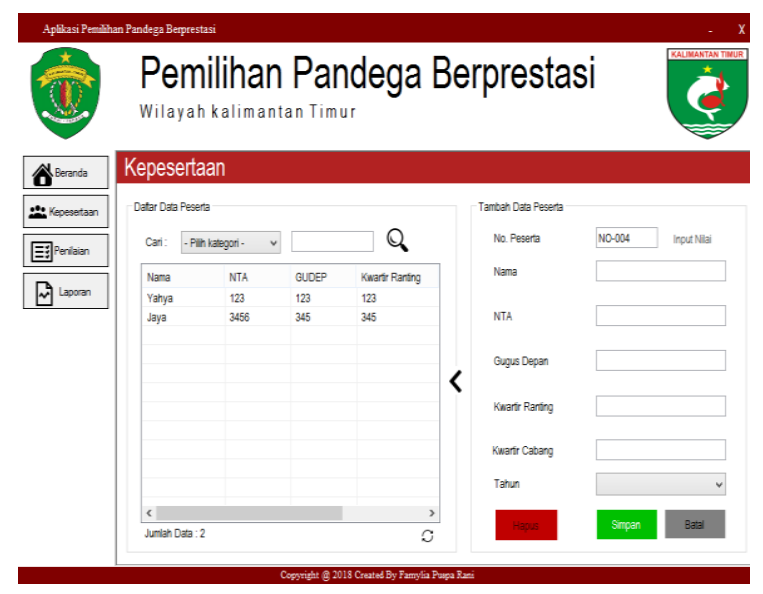

Gambar 2. Halaman Kepesertaan

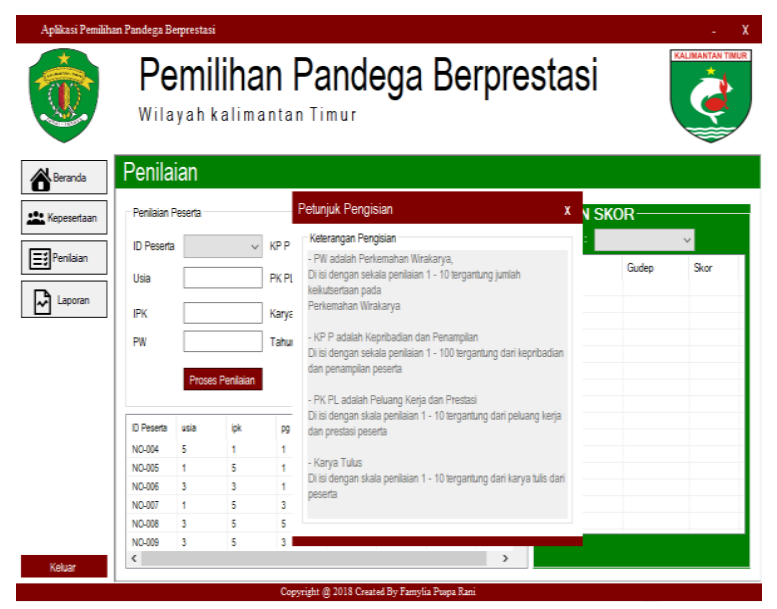

Gambar 3. Halaman Penilaian

Gambar 3 untuk melakukan penilaian serta terdapat petunjuk pengisian penilaian seperti pada Gambar 4.

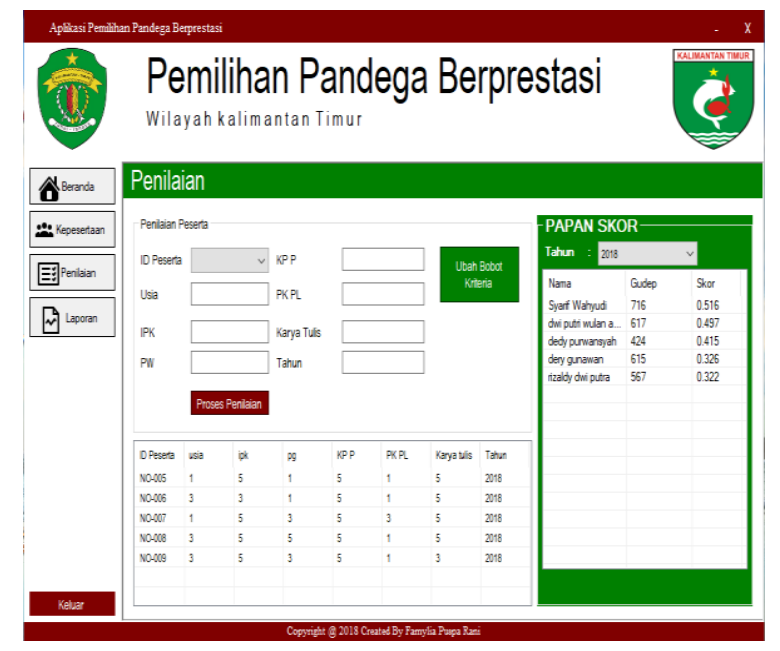

Gambar 4. Halaman Petunjuk Pengisian

Pada halaman laporan admin dapat melakukan pencetakan laporan berdasaran tahun maupun keseluruhan, halaman ini berisi data penilaian serta data kepesertaan.

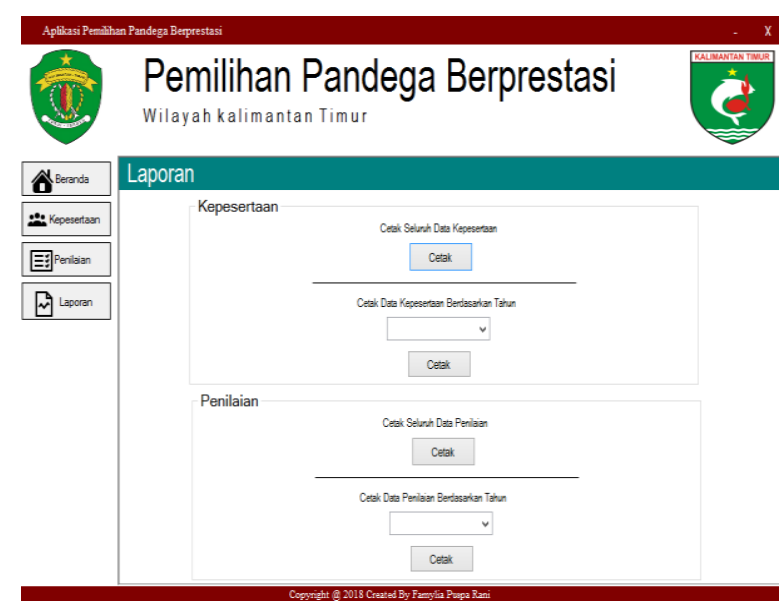

Gambar 5. Menu Laporan

\subsection{Pengujian Aplikasi}

Untuk mengetahui kelayakan sistem apakah telah sesuai dengan menggunakan perhitungan manual. Menggunakan data 4 tahun terakhir peserta pandega berprestasi. Pengujian dilakukan menggunakan data peserta tahun 2017. Tingkat nilai kecocokan alternatif pada setiap atribut dengan nama-nama peserta adalah sebagai berikut :
1) A1 = Rizaldy Dwi Putra
2) A2 = Dery Gunawan
3) A3 = Dwi Putri Wulan Anggraeni
4) A4 = Syarif Wahyudi
5) A5 = Dedy Purwansyah

Terdapat 6 kriteria yang digunakan dalam sistem pendukung keputusan ini yang dapat dilihat sebagai berikut :
a. $\mathrm{U}=\mathrm{Usia}(\mathrm{C} 1)$
b. IPK = Indeks Prestasi Kumulatif (C2)
c. $\mathrm{PW}=$ Perkemahan Wirakarya (C3)
d. $K P / P=$ Kepribadian dan Penampilan (C4)
e. $\quad \mathrm{PK} / \mathrm{PP}=$ Peluang Kerja dan Prestasi Lain (C5)
f. $\quad \mathrm{KT}=$ Karya Tulis (C6)

Tabel 4.1 Data Sebelum di Konversi

\begin{tabular}{lccccccc}
\hline \multirow{2}{*}{ No. } & \multirow{2}{*}{ Alternatif } & \multicolumn{6}{c}{ Kriteria } \\
& & C1 & C2 & C3 & C4 & C5 & C6 \\
\hline 1. & A1 & 21 & 3.80 & 3 & 80 & 4 & 82 \\
2. & A2 & 22 & 3.35 & 3 & 85 & 4 & 77 \\
3. & A3 & 21 & 3.75 & 4 & 79 & 5 & 80 \\
4. & A4 & 22 & 3.58 & 5 & 85 & 3 & 80 \\
5. & A5 & 22 & 3.88 & 4 & 84 & 3 & 75 \\
\hline
\end{tabular}

Tabel 4.2 Rating Kecocokan Setiap Alternatif pada Setiap Kriteria

\begin{tabular}{cccccccc}
\hline \multirow{2}{*}{ No. Alternatif } & C1 & C2 & C3 & C4 & C5 & C6 \\
\hline 1. & A1 & 1 & 5 & 1 & 5 & 1 & 5 \\
2. & A2 & 3 & 3 & 1 & 5 & 1 & 5 \\
3. & A3 & 1 & 5 & 3 & 5 & 3 & 5 \\
4. & A4 & 3 & 5 & 5 & 5 & 1 & 5 \\
5. & A5 & 3 & 5 & 3 & 5 & 1 & 3 \\
\hline
\end{tabular}


Ramadiani, dkk, Sistem Pendukung Keputusan ... 159

Pada Tabel 4.2 merupakan data yang telah di konversi ke dalam skala kriteria sehingga lebih mudah untuk proses selanjutnya yaitu pembentukan matriks dengan bobot kriteria yang telah ditentukan.

Tahap selanjutnya adalah menampilkan semua data yang mendukung atribut dalam bentuk perkalian matriks keputusan. $X$ merupakan nilai atribut dari setiap atribut yang diperesentasikan sebagai perkalian matriks. Berikut adalah matriks keputusan yang dihasilkan:

$$
x \text { (Matrix Keputusan })=\left[\begin{array}{llllll}
1 & 5 & 1 & 5 & 1 & 5 \\
3 & 3 & 1 & 5 & 1 & 5 \\
1 & 5 & 3 & 5 & 3 & 5 \\
3 & 5 & 5 & 5 & 1 & 5 \\
3 & 5 & 3 & 5 & 1 & 3
\end{array}\right]
$$

Tahapan selanjutnya adalah menyimpulkan bahwa denominator, merupakan hasil keputusan terbaik adri akar kuadrat melalui penjumlahan kuadrat pada setiap alternatif per atribut.

Kolom 1

$$
\begin{gathered}
X_{11}=\frac{1}{\sqrt{1^{2}+3^{2}+1^{2}+3^{2}+3^{2}}}=\frac{1}{\sqrt{1+9+1+9+9}} \\
=\frac{1}{5,385}=0,186 \\
X_{21}=\frac{3}{\sqrt{1^{2}+3^{2}+1^{2}+3^{2}+3^{2}}}=\frac{3}{\sqrt{1+9+1+9+9}} \\
=\frac{3}{5,385}=0,557 \\
X_{31}=\frac{1}{\sqrt{1^{2}+3^{2}+1^{2}+3^{2}+3^{2}}}=\frac{1}{\sqrt{1+9+1+9+9}} \\
X_{41}=\frac{1}{\sqrt{1^{2}+3^{2}+1^{2}+3^{2}+3^{2}}}=0,186 \\
X_{51}=\frac{3}{\sqrt{1+985}}=0,557 \\
\sqrt{5,385}
\end{gathered}
$$

Kolom 2

$$
\begin{aligned}
& X_{12}=\frac{5}{\sqrt{5^{2}+3^{2}+5^{2}+5^{2}+5^{2}}}=\frac{5}{\sqrt{25+9+25+25+25}} \\
& =\frac{5}{10,440}=0,479 \\
& X_{22}=\frac{3}{\sqrt{5^{2}+3^{2}+5^{2}+5^{2}+5^{2}}}=\frac{3}{\sqrt{25+9+25+25+25}} \\
& =\frac{3}{10,440}=0,287 \\
& X_{32}=\frac{5}{\sqrt{5^{2}+3^{2}+5^{2}+5^{2}+5^{2}}}=\frac{5}{\sqrt{25+9+25+25+25}} \\
& =\frac{5}{10,440}=0,479 \\
& X_{42}=\frac{5}{\sqrt{5^{2}+3^{2}+5^{2}+5^{2}+5^{2}}}=\frac{5}{\sqrt{25+9+25+25+25}} \\
& =\frac{5}{10,440}=0,479 \\
& X_{52}=\frac{5}{\sqrt{5^{2}+3^{2}+5^{2}+5^{2}+5^{2}}}=\frac{5}{\sqrt{25+9+25+25+25}} \\
& =\frac{5}{10,440}=0,479
\end{aligned}
$$

Kolom 3

$$
X_{13}=\frac{1}{\sqrt{1^{2}+1^{2}+3^{2}+5^{2}+3^{2}}}=\frac{1}{\sqrt{1+1+9+25+9}}
$$

$$
\begin{gathered}
=\frac{1}{0,447}=0,149 \\
X_{23}=\frac{1}{\sqrt{1^{2}+1^{2}+3^{2}+5^{2}+3^{2}}}=\frac{1}{\sqrt{1+1+9+25+9}} \\
=\frac{1}{0,447}=0,149 \\
X_{33}=\frac{3}{\sqrt{1^{2}+1^{2}+3^{2}+5^{2}+3^{2}}}=\frac{3}{\sqrt{1+1+9+25+9}} \\
=\frac{3}{0,447}=0,447 \\
X_{43}=\frac{5}{\sqrt{1^{2}+1^{2}+3^{2}+5^{2}+3^{2}}}=\frac{5}{\sqrt{1+1+9+25+9}} \\
\quad=\frac{5}{0,447}=0,745 \\
X_{53}=\frac{3}{\sqrt{1^{2}+1^{2}+3^{2}+5^{2}+3^{2}}}=\frac{3}{\sqrt{1+1+9+25+9}} \\
=\frac{3}{0,447}=0,447
\end{gathered}
$$

Kolom 4

$$
\begin{aligned}
X_{14}=\frac{5}{\sqrt{5^{2}+5^{2}+5^{2}+5^{2}+5^{2}}} & =\frac{5}{\sqrt{25+25+25+25+25}} \\
=\frac{5}{11,180} & =0,447 \\
X_{24}=\frac{5}{\sqrt{5^{2}+5^{2}+5^{2}+5^{2}+5^{2}}} & =\frac{5}{\sqrt{25+25+25+25+25}} \\
=\frac{5}{11,180} & =0,447 \\
X_{34}=\frac{5 \quad}{\sqrt{5^{2}+5^{2}+5^{2}+5^{2}+5^{2}}} & =\frac{5}{\sqrt{25+25+25+25+25}} \\
X_{44}=\frac{5}{\sqrt{5^{2}+5^{2}+5^{2}+5^{2}+5^{2}}} & =\frac{5}{\sqrt{11,180}}=0,447 \\
X_{54}=\frac{5}{11,180} & =0,447 \\
\sqrt{5^{2}+5^{2}+5^{2}+5^{2}+5^{2}} & =\frac{5}{\sqrt{25+25+25+25+25}} \\
=\frac{5}{11,180} & =0,447
\end{aligned}
$$

Kolom 5

$$
\begin{gathered}
X_{15}=\frac{1}{\sqrt{1^{2}+1^{2}+3^{2}+1^{2}+1^{2}}}=\frac{1}{\sqrt{1+1+9+1+1}} \\
=\frac{1}{3,605}=0,277
\end{gathered}
$$$$
X_{25}=\frac{1}{\sqrt{1^{2}+1^{2}+3^{2}+1^{2}+1^{2}}}=\frac{1}{\sqrt{1+1+9+1+1}}
$$$$
=\frac{1}{3,605}=0,277
$$$$
X_{35}=\frac{3}{\sqrt{1^{2}+1^{2}+3^{2}+1^{2}+1^{2}}}=\frac{3}{\sqrt{1+1+9+1+1}}
$$$$
=\frac{3}{3,605}=0,832
$$$$
\mathrm{X}_{45}=\frac{1}{\sqrt{1^{2}+1^{2}+3^{2}+1^{2}+1^{2}}}=\frac{1}{\sqrt{1+1+9+1+1}}
$$$$
=\frac{1}{3,605}=0,277
$$$$
\mathrm{X}_{55}=\frac{1}{\sqrt{1^{2}+1^{2}+3^{2}+1^{2}+1^{2}}}=\frac{1}{\sqrt{1+1+9+1+1}}
$$$$
=\frac{1}{3,605}=0,277
$$

Kolom 6

$$
\begin{aligned}
X_{16}=\frac{5}{\sqrt{5^{2}+5^{2}+5^{2}+5^{2}+3^{2}}} & =\frac{5}{\sqrt{25+25+25+25+9}} \\
=\frac{5}{10,440} & =0,479 \\
X_{26}=\frac{5}{\sqrt{5^{2}+5^{2}+5^{2}+5^{2}+3^{2}}} & =\frac{5}{\sqrt{25+25+25+25+9}} \\
=\frac{5}{10,440} & =0,479
\end{aligned}
$$




$$
\begin{aligned}
& X_{36}=\frac{5}{\sqrt{5^{2}+5^{2}+5^{2}+5^{2}+3^{2}}}=\frac{5}{\sqrt{25+25+25+25+9}} \\
& =\frac{5}{10,440}=0,479 \\
& X_{46}=\frac{5}{\sqrt{5^{2}+5^{2}+5^{2}+5^{2}+3^{2}}}=\frac{5}{\sqrt{25+25+25+25+9}} \\
& =\frac{5}{10,440}=0,479 \\
& X_{56}=\frac{3}{\sqrt{5^{2}+5^{2}+5^{2}+5^{2}+3^{2}}}=\frac{3}{\sqrt{25+25+25+25+9}} \\
& =\frac{3}{10,440}=0,287
\end{aligned}
$$

Setelah dilakukan perhitungan didapatkan nilai dari matrix normalisasi :

$$
\text { Matrix Normalisasi }=\left[\begin{array}{llllll}
0,186 & 0,479 & 0,149 & 0,447 & 0,277 & 0,479 \\
0,557 & 0,287 & 0,149 & 0,447 & 0,277 & 0,479 \\
0,186 & 0,479 & 0,447 & 0,447 & 0,832 & 0,479 \\
0,557 & 0,479 & 0,745 & 0,447 & 0,277 & 0,479 \\
0,557 & 0,479 & 0,447 & 0,447 & 0,277 & 0,287
\end{array}\right]
$$

\begin{tabular}{|c|c|c|c|c|}
\hline No & Peserta & $\begin{array}{l}\text { Perhitunga } \\
\text { n Manual }\end{array}$ & $\begin{array}{l}\text { Uji } \\
\text { Sistem }\end{array}$ & Ket. \\
\hline 1 & $\begin{array}{l}\text { Rizaldy Dwi } \\
\text { Putra }\end{array}$ & 0,322 & 0,322 & Tidak Lolos \\
\hline 2 & Dery Gunawan & 0,326 & 0,326 & Tidak Lolos \\
\hline 3 & $\begin{array}{l}\text { Dwi Putri W. } \\
\text { Anggraeni }\end{array}$ & 0,497 & 0,497 & Lolos \\
\hline 4 & $\begin{array}{l}\text { Syarif } \\
\text { Wahyudi }\end{array}$ & 0,516 & 0,516 & Lolos \\
\hline 5 & $\begin{array}{l}\text { Dedy } \\
\text { Purwansyah }\end{array}$ & 0,415 & 0,415 & Lolos \\
\hline
\end{tabular}

Nilai $Y_{i}$ berniali positif atau negatif bergantung pada jumlah maksimal atribut benefit dan jumlah minimal atribut cost pada perkalian keputusan (matriks).

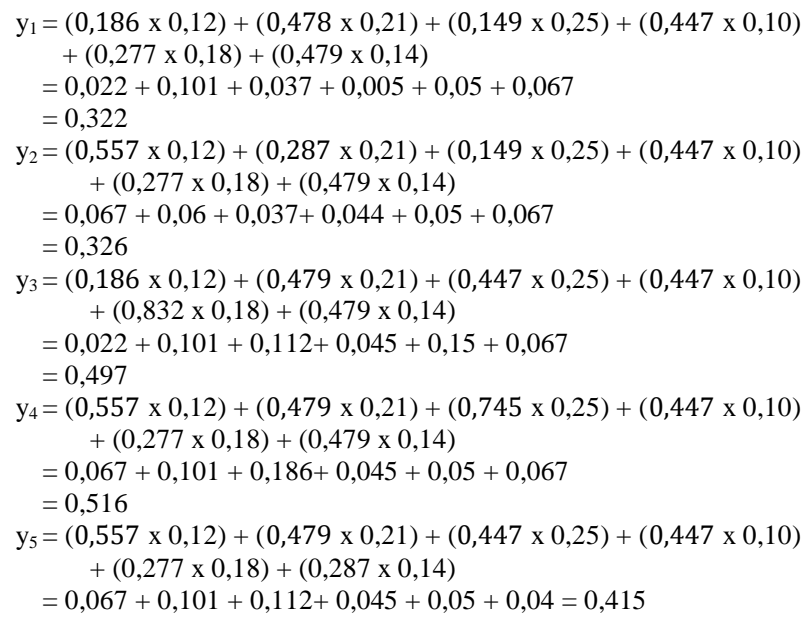

Tabel 4.3 Hasil Uji Coba

Sehingga dapat dilakukan perangkingan sebagai langkah terakhir dengan nilai akhir pada $\mathrm{y}_{1}=0,322$, $\mathrm{y}_{2}=0,326, \quad \mathrm{y}_{3}=0,497, \quad \mathrm{y}_{4}=0,516, \quad \mathrm{y}_{5}=0,415$. Maka rekomendasi yang diperoleh dengan perangkingan adalah :

Terbaik $1=\mathrm{y}_{4}$ dengan nilai 0,516

Terbaik $2=\mathrm{y}_{3}$ dengan nilai 0,497

Terbaik $3=y_{5}$ dengan nilai 0,415
Terbaik $4=\mathrm{y}_{2}$ dengan nilai 0,326

Terbaik $5=\mathrm{y}_{1}$ dengan nilai 0,322

Pada Tabel 4.3 menjelaskan tentang hasil uji coba antar perhitungan manual dengan perhitungan dalam sistem kemudian disesuaikan dengan fakta dilapangan apakah telah sesuai atau belum. Dan hasil yang diperoleh memiliki tingkat akurasi $100 \%$. Dengan pengujian melalui rumus tingkat akurasi dari data asli dengan sistem Kwartir Cabang Kalimantan Timur, berikut ini adalah cara penghitungan tingkat akurasi program :

$\begin{array}{ll}\text { a. data responden pramuka pandega } & : 5 \\ \text { b. data hasil sama dengan data original } & : 5 \\ \text { c. data hasil tidak sama dengan data original : } 0\end{array}$

$$
\text { Akurasi }=\frac{N}{N+N i} \times 100 \%
$$

Dengan nilai $N$ ialah total sesuai, $N_{i}$ ialah total tidak sesuai.

$$
\text { Akurasi }=\frac{5}{5+0} \times 100 \%=100 \%
$$

Data yang dihasilkan dalam penelitian ini sebesar $100 \%$ yang artinya memiliki nilai akurasi yang signifikan. Menggunakan 5 data asli maupun manual diuji setelah dimasukan ke dalam sistem.

\section{KESIMPULAN}

Penelitian ini telah menghasilkan aplikasi pemilihan pramuka pandega berprestasi menggunakan metode MOORA dengan tingkat akurasi $100 \%$, dari hasil perhitungan manual dengan perhitungan pada system. Sistem ini menjadi rekomendasi bagi kepala bidang bina muda kwartir daerah Kalimantan Timur untuk memudahkan perangkingan dan pemilihan Pramuka Pandega berprestasi.

\section{DAFTAR PUSTAKA}

A. MUHAMMAD, 2016. Aplikasi Pemilihan Bibit Budidaya Ikan Air Tawar Dengan Metode MOORA-Entropy. Universitas Islam Negeri Syarif Hidayatullah : Jakarta.

FEBININGTYAS, E., 2016. Implementasi Metode MOORA Untuk Menentukan Bonus Karyawan Pada PT. Lestari Jaya Farma. Fakultas Teknik. Universitas Nusantara PGRI : Kediri.

F. EKA, 2016. Perancangan sistem pendukung keputusan pemberian bonus karyawan menggunakan metode MOORA. Universitas Nusantara PGRI : Kediri

K. H. Rivalri, 2017. Multi Objective Optimization On The Basis Of Ratio Analysis Method. Stimik Budi Dharma: Medan.

MUSYAWARAH BESAR, 2016, Laporan Pertanggung Jawaban Gerakan Pramuka Kwartir Daerah Kalimantan Tmur. Bontang: Kwartir Daerah.

O. LAUDIA, 2016. Sistem Pendukung Keputusan Hasil Kelayakan Cetakan Buku menggunakan Metode MOORA. Politeknik Negeri Malang : Malang. 
RAMADIANI, R., \& RAHMA, A. (2019). Sistem pendukung keputusan pemilihan tenaga kesehatan teladan menggunakan metode Multi-Attribute Utility Theory. Register: Jurnal Ilmiah Teknologi Sistem Informasi, 5 (1), 1-12. http://www.journal.unipdu.ac.id/index.php/register

RAMADIANI, REYNALDI KURNIAWAN, 2018. Application of Technique for Order Preference Method by Similarity to Ideal Solution (TOPSIS) Priority of KORPRI Housing Recipient. International Journal of Engineering, Information Science and Applied Sciences (IJEIS-AS) . http://journal.stkipsingkawang.ac.id/index.php/IJEI S-AS/article/view/526

RAMADIANI, DYNA MARISA K, MUHAMMAD LABIB JUNDILLAH, AZAINIL, HELIZA RAHMANIA H. 2018. Simple Additive Weighting to Diagnose Rabbit Disease. The 2nd International Conference on Energy, Environmental and Information System (ICENIS 2017), Semarang, Indonesia, E3S Web of Conferences, Vol. 31, id.10002, EDP Sciences. DOI: 10.1051/e3sconf/20183110002 https://www.e3sconferences.org/articles/e3sconf/abs/2018/06/e3sco nf_icenis2018_10002/e3sconf_icenis2018_10002.h tml

ROGER, S. PRESSMAN, (2012). "Rekayasa Perangkat Lunak (Pendekatan Praktisi) Edisi 7 : Buku 1", Yogyakarta : Andi.

TURBAN, E., 2005. Decision Support System and Inteligent Systems. Jilid1. Edisi 7. Yogyakarta: Penerbit Andi. 
Halaman ini sengaja dikosongkan 